\title{
On the Determination of the Main Parameters of a Dam Compactor
}

\author{
Maksud S. Karimov* \\ Tashkent Institute of Irrigation and Agricultural \\ Mechanization Engineers \\ Tashkent, Uzbekistan
}

Received 26.03.2020, received in revised form 14.04.2020, accepted 21.05.2020

Abstract. The article highlights the issues of determining the main parameters of a dam compactor of a mounted trencher for cutting temporary sprinklers. It also finds out the angle of advance of the compaction soil of the inner part of the ditch using a conical roller and the outer part of the ditch that determines the parameters of the ditch and working body.

Keywords: sprinklers, trencher, the angle of advance, dam, dam compactor, angle of repose, conical roller, sprinkler width, channel depth, conical roller diameter.

Citation: Karimov M.S. On the determination of the main parameters of a dam compactor, J. Sib. Fed. Univ. Eng. \& Technol., 2020, 13(5), 626-631. DOI: 10.17516/1999-494X-0251

\section{К определению основных параметров дамбоуплотнителя}

\author{
М.С. Каримов \\ Ташкентский институт инженеров ирригаџии \\ и механизации сельского хозяйства \\ Узбекистан, Ташкент
}

\begin{abstract}
Аннотация. В статье освещены вопросы определения основных параметров дамбоуплотнителя навесного траншеекопателя для резки временных спринклеров, а также определяется угол продвижения грунта уплотнения внутренней части котлована с помощью конического ролика и наружной части котлована с пластиной, определяющей параметры рва и рабочего органа.

Ключевые слова: временные спринклеры, траншеекопатель, угол опережения, плотина, уплотнитель плотины, угол естественного откоса, конический каток, ширина спринклера, глубина канала, диаметр конического ролика.
\end{abstract}

(C) Siberian Federal University. All rights reserved

This work is licensed under a Creative Commons Attribution-Non Commercial 4.0 International License (CC BY-NC 4.0).

* Corresponding author E-mail address: kms19600513@gmail.com 
Цитирование: Каримов М.С. К определению основных параметров дамбоуплотнителя / М.С. Каримов // Журн. Сиб. федер. ун-та. Техника и технологии, 2020. 13(5). С. 626-631. DOI: 10.17516/1999-494X-0251

It is known that for compaction of soils, compactors with sliding, rolling and vibrating working bodies are used.

The working process of each type of compacting devices consists in soil compaction without bulging it on the surface of the dam, that is, without their longitudinal and transverse movement [10, $11,12]$.

As a result of patent and engineering studies, we determined and justified the parameters of a channel digger that provides the smallest dead depth and high dams. However, it turned out that in order to increase the water holding capacity of the dams of the temporary irrigation, they need to be compacted in order to reduce the amount of irrigation water for washing the dams of the irrigator [3].

Studies show that the shape of the cross section of the temporary sprinkler dam after the passage of the trencher is significantly different from the shape that is obtained at the time of its formation [1].

The poured soil, crumbling at an angle of repose, gives the cross-section of the dam a trapezoidal shape (Fig. 1).

Cutting of temporary sprinklers with a backhoe as well as parameters of the cutting depth of the soil should meet the requirement of predetermining the top width of the dam. Therefore, the above parameters cannot be arbitrary [1].

When determining the volume of soil displaced by the digger, the angle of rupture is equal to the angle of repose, i.e.:

$$
\varphi_{o \sigma}=\varphi_{H}=\varphi .
$$

Then, the displaced volume of soil can be determined by the cross-sectional area (S1) taken out by the channel digger $[1,3]$.

$$
S_{1}=b\left(H_{b}-h\right)-2\left(H_{b}-h\right)-\operatorname{ctg} \varphi-4 h \operatorname{ctg} \varphi\left(H_{b}-h\right) .
$$

Converting of the expression (1) will lead to the following form:

$$
\left.S_{1}=b H_{b}-b h-2 H_{b}^{2}-h\right)+2 h^{2} \operatorname{ctg} \varphi,
$$

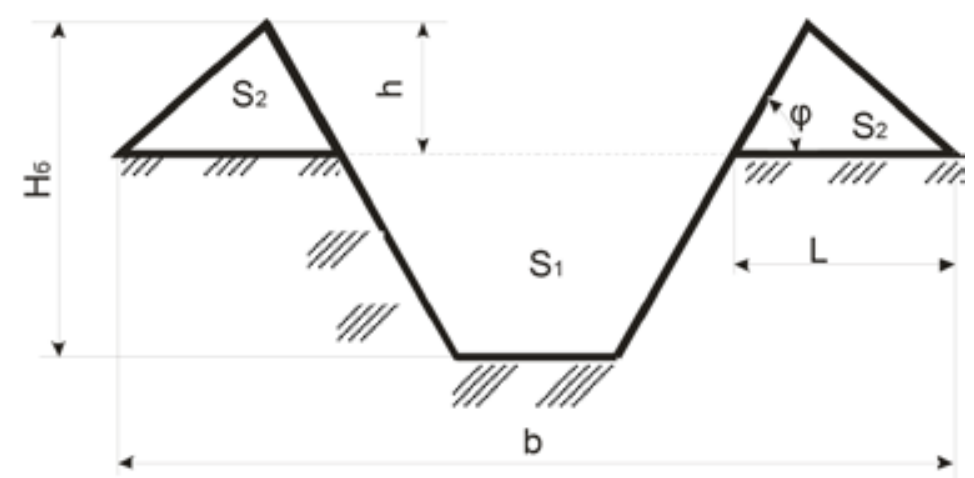

Fig. 1. Scheme of temporary irrigator dam 
where $b$ - width of the occupied strip of the dam or of the temporary sprinkler; $h$ - dam height, m; $H_{b}$ - depth of temporary sprinkler, $\mathrm{m} ; \varphi$ - angle of repose of the soil, deg.

The cross-sectional area (S2) of the volume of soil laid by the trencher in the crest of the dam can be determined from the expression:

$$
S_{2}=2 \frac{S_{1}}{2}=2 h^{2} \operatorname{ctg} \varphi
$$

Since the coefficient of soil fluffiness when cutting temporary irrigators is equal to one [1,2], the volume of soil taken out by the channel digger will be equal to the volume of soil laid in the crest of the dam, i.e.:

$$
S_{1}=2 S_{2}
$$

Equating the expressions (2) and (3), we obtain the following equation:

$$
b H_{b}-b h-2 H_{b}^{2}=0 .
$$

From equation (4) we determine the height of the crest of the temporary sprinkler dam:

$$
H=\frac{H_{\tilde{\sigma}}\left(b-2 H_{\tilde{\sigma}}\right)}{b} \text {. }
$$

Analysis of equation (4) shows that the height $(\mathrm{H})$ of the dam depends on the depth $\left(H_{b}\right)$ of the temporary sprinkler and the width (b) of the strip of the dam.

The width of the strip of the dam or the temporary sprinkler is equal:

$$
b=B+2\left(H_{b}-h_{1}\right) \operatorname{ctg} \varphi ; b=B+2 H_{b} \operatorname{ctg} \varphi-2 h_{1} \operatorname{ctg} \varphi .
$$

The solution of equation (6) with respect to the width of the dam at the top will lead to the following form:

$$
B=b-2 \operatorname{ctg} \varphi\left(H_{b}-h_{1}\right) \text {. }
$$

The results of early studies of the shape of the formed dam when cutting temporary sprinklers and its compaction show the effectiveness of the conical shape of the roller [1].

During operation, the conical roller rotates on its axis with a sliding characteristic typical to passive compacting rollers, that is, having no rotating torque on the shaft. To find out the effect of sliding on the longitudinal displacement of compacted soil particles on the surface of the dam, we graphically consider the nature of the impact of the base of the conical part of the roller on them. Suppose that a conical roller moves with sliding (Fig. 2).

By decomposing the normal pressure force into the components $Q_{m}$ and $T_{m}$ we can assume the following, if:

1. $T_{m} \leq F_{2}$, then the surface particle under the force of $Q_{m}$ moves more along the dam rather than deep into it;

2. $T_{m}>F_{2}$, the resultant of external forces $Q_{m}$ deviates from the normal pressure $N_{m}$ at an angle $\varphi_{2}$ in the direction opposite to the rotation of the roller. In this case, the longitudinal movement $\mathrm{mm}^{\prime}$ of surface soil particles will be greater than the movement into the depth $Q^{\prime} m^{\prime}$ of the dam;

3. It can be easily seen that the resultant of forces is determined from the expression: 


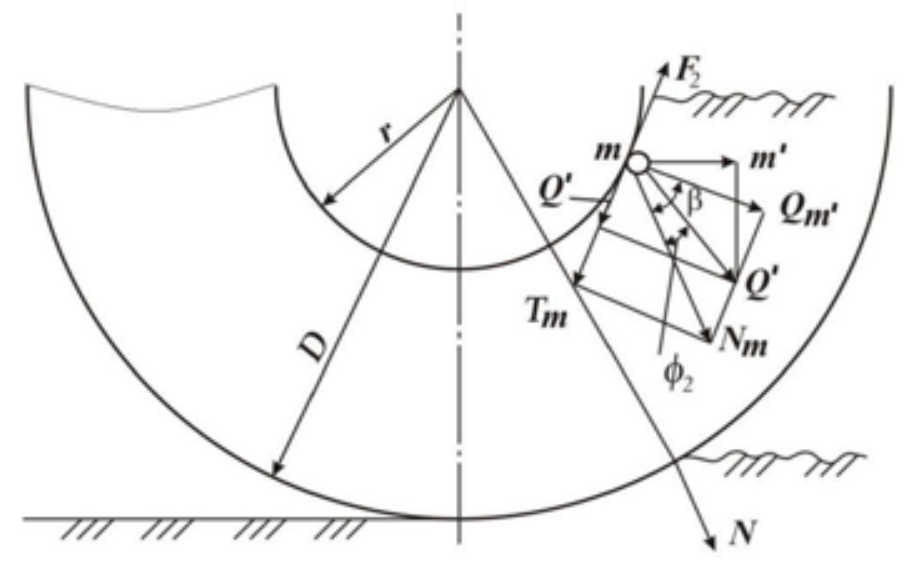

Fig. 2. On the substantiation of the dam compactor parameters

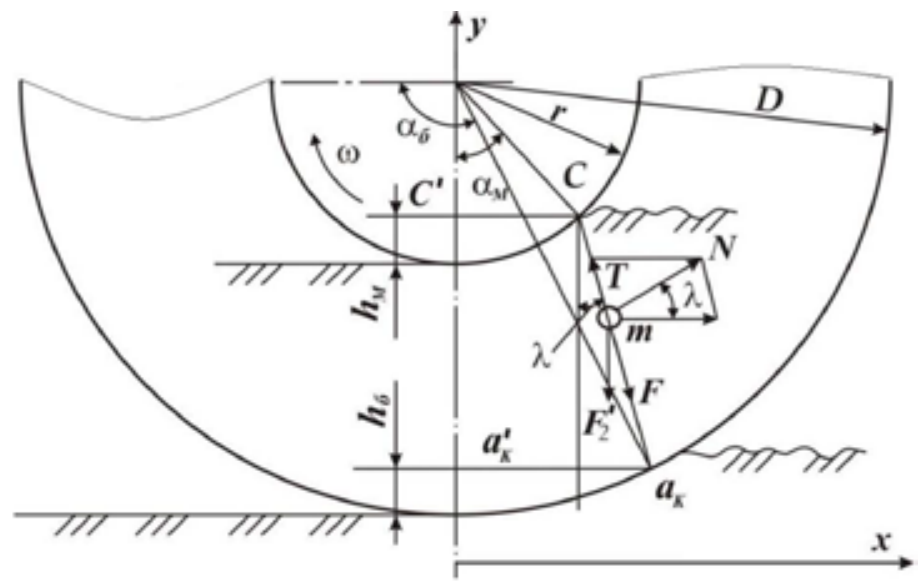

Fig. 3. On the determination of the angle of advance of soil compaction by conical roller on the slope of the dam

$$
Q^{\prime}=N_{m}\left(\operatorname{tg} \beta-\operatorname{tg} \varphi_{2}\right) .
$$

Whence it follows that the larger the angle $\beta$ and the smaller $\varphi_{2}$, i.e. the smoother the roller surface, the less $Q_{m}^{\prime}$ deviates from $N_{m}$, and the greater is the immersion of the soil particles into the dam.

Consequently, the least compaction of the dam soil by sliding rollers is achieved at lower values of the angle of external friction of the soil.

For example, the conical part of the roller compacts the soil of the dam slopes with the depth of immersion of the large base and the small base (Fig. 3).

$$
\operatorname{tg} \alpha=\frac{l^{\prime \prime}}{l} ; l^{\prime \prime}=a^{k} a^{\prime} k-C_{k} C_{k}^{\prime},
$$

where $l^{\prime \prime}$ - length of the opposite leg, $\mathrm{m} ; l^{\prime \prime}$ - length of the adjacent leg of the lead angle of compaction, $\mathrm{m}$.

$$
l^{\prime \prime}=D \sin \alpha_{b}-r \sin \alpha_{m} ; l=D-h_{b}-r \sin \alpha_{m},
$$

where $D$ and $r$-the radii of the large and small bases of the truncated cone of rollers; $\alpha_{b}$ and $\alpha_{m}-$ angles of immersion in the soil, deg. 
Substituting the values found in the above formula, we obtain:

$$
\operatorname{tg} \lambda=\frac{D \sin \alpha_{b}-r \sin \alpha_{m}}{D-h_{b}-r \cos \alpha_{m}}
$$

where $\mathrm{hb}$ - the depth of immersion of the large base, $\mathrm{m}$.

Hence:

$$
h_{b}=D-D \cos \alpha_{b}-R\left(1-\cos \alpha_{b}\right)=2 D \sin \frac{2 \alpha_{b}}{2} .
$$

$$
\operatorname{tg} \lambda=\frac{D \sin \alpha_{b}-r \sin \alpha_{m}}{D \cos \alpha_{b}-r \cos \alpha_{m}} .
$$

If the angles of immersion of the large and small bases are the same, i.e. $\sin \alpha b=\alpha m$, then:

$$
\operatorname{tg} \lambda=\operatorname{tg} \lambda
$$

This means that the angle of advance of compaction is equal to the angle of immersion of the roller base. Therefore, according to equation (12), the greater the immersion angle of the conical base of the roller, the greater the angle of advance of compaction:

$$
\begin{aligned}
& \cos \alpha_{b}=\frac{D-h_{b}}{D} . \\
& \sin \alpha_{b}=\frac{1}{D} \sqrt{h_{b}\left(2 D-h_{b}\right)} .
\end{aligned}
$$

Similarly, we define:

$$
\begin{aligned}
& \sin \alpha_{m}=\frac{r-h_{m}}{r} . \\
& \sin \alpha_{m}=\frac{1}{2} \sqrt{h_{m}\left(2 r-h_{m}\right)} .
\end{aligned}
$$

Substituting the values of the values found in the formula (12) and after a series of transformations, we obtain:

$$
\operatorname{tg} \lambda=\frac{\sqrt{h_{b}\left(2 R-h_{b}\right)-h_{m}\left(2 r-h_{m}\right)}}{D-r-h_{b}+h_{m}} .
$$

From expression (18) it follows that with increasing immersion depth $\left(h_{m}\right)$ of the roller small base, the angle of advance of the compaction decreases, and with increasing immersion depth (h) of the roller large base - it increases. With an increase in the radius (r) of the small base, the angle of advance of the compaction decreases, while with an increase in the radius (D) of the large base, it increases. If the immersion depth of both bases of the roller is the same, i.e. $h_{b}=h_{m}=h$, then formula (18) takes the form:

$$
\operatorname{tg} \lambda=\frac{\sqrt{h(2 D-h)-\left(2 r-h_{m}\right)}}{D-r} .
$$

So the greater the difference between the radii of the greater and lesser bases of the roller, the greater the angle of advance of the compaction. 
Assuming that the roller stands still, i.e. $v=0$ and $Q=0$, and using the limiting values of the angle $\lambda$, which will be equal to the angle $\varphi_{2}$ at which the subsidence of the soil particles of the dam is completely eliminated, then in equality (19) it is possible to establish the relationship of radii $D$ and $r$ :

$$
R=\frac{\operatorname{tg} \varphi_{2} \cos \alpha_{m}-\sin \alpha_{m}}{\operatorname{tg} \varphi_{2} \cos \alpha_{b}-\sin \alpha_{b}} \cdot r
$$

The relationship between the angle of advance of the compaction and the diameter of the conical roller is established. Analytical dependences for determination of large and small diameter of a conic roller are deduced.

Studies have established that in order to obtain the greatest effect of dam compaction, the main parameters of the dam packer should be as follows: a large diameter of the cone roller $540 \mathrm{~mm}$, ski length $643 \mathrm{~mm}$, ski width $360 \mathrm{~mm}$ and the angle of the dam $30^{\circ}$.

\section{References}

[1] Slobodyuk P.I. Research and substantiation of parameters of the working body for cutting irrigation furrows at different speeds. Diss... cand. of tech. Sci. Yangiyul, 1967, 200 p.

[2] Doganovskii M.G. The technological process of work of the corps of hiller in the formation of grooves and ridges. Proceedings of VIM, M.,1951, Vol.13, 3-12

[3] Bahramov F.H. Substantiation of the parameters of the working body of the channel digger for cutting temporary irrigators. Thesis... cand. of tech. Sci, Yangiyul, 1995. 17 p.

[4] Goberman L.A. Fundamentals of theory, calculation and design of construction and road machines. M., 1988. 464 p.

[5] Surikov V.V. and others. Construction machines for mechanization of reclamation works. M., 1991. $463 \mathrm{p}$.

[6] I. Measures of Reclamation etc. of the machine. M.: Agropromizdat, 1991.

[7] Vasiliev B.A. Land reclamation and construction machines, M., 1986, 431 p.

[8] Directory of designer road cars. Under edition of Dr. sci.Sciences, prof. I.P. Borodacheva. M.: Mechanical engineering, 1973.

[9] Below V.I. Average construction of the machine with the working bodies with intensifitsiruetsa action. M., 1981.

[10] Andreev A.A. Experience in the analytical study of rolling a hard wheel with the formation of a rut. Journal of Agricultural Machines, 1955, 2.

[11] Kaluzhskiy Ya.A. Resistance to movement of rollers during the compaction of soil. Proceedings of the Kharkov Road Institute. Kharkov, 1950.

[12] Saakyan S.S. The interaction of the driven wheel with the soil. Agricultural mechanics. M.: Mashinostroyeniye, 1967. 